\title{
Auriculotherapy: neurophysiology, points to choose, indications and results on musculoskeletal pain conditions: a systematic review of reviews
}

\author{
Auriculoterapia: neurofisiologia, pontos de escolha, indicações e resultados em condições \\ dolorosas musculoesqueléticas: revisão sistemática de revisões
}

Dérrick Patrick Artioli ${ }^{1}$, Alana Ludemila de Freitas Tavares², Gladson Ricardo Flor Bertolini ${ }^{2}$

DOI 10.5935/2595-0118.20190065

\section{ABSTRACT}

BACKGROUND AND OBJECTIVES: Auriculotherapy is widely used to relieve painful conditions, therefore, allowing systematic reviews on the subject. However, they did not propose a unified bank of points of possible choice, their possible combinations or described the location of such points, thus making it the objective of this study.

CONTENTS: The systematic review of revisions methodology (Overview) was chosen to achieve the proposed goal. The quality of such material was ascertained by the tool Assessment of Multiple Systematic Reviews, and the databases consulted were PEDro database, Pubmed, Scielo, and LILACS. The keywords and boolean index applied were: auriculotherapy AND pain; ear acupuncture AND pain, ear acupressure AND pain; auricular therapy and pain; auricular medicine AND pain. A total of 242 studies were found, but only six were systematic reviews in humans involving pain and auriculotherapy alone (without association with another technique). The methodological quality of the studies was high (8-10/11 Assessment of Multiple Systematic Reviews). There is variability in the neurophysiological explanation of action, many possible disorders that can be approached with auriculotherapy (acute, chronic, trauma, pre- and postoperative pain among others). Auriculotherapy showed to be promising in the remission of the pain, adjunct to the conventional treatment, low risk, cost, and easy administration.

CONCLUSION: There are several ways of justifying its neurophysiological effects, and the most used points were ShenMen, the corresponding somatotopic region and the cavum conchae region (vagal stimulation). Auriculotherapy meets the needs of

Dérrick Patrick Artioli - Dhttps://orcid.org/0000-0003-3259-1725;

Alana Ludemila de Freitas Tavares - (Dhttps://orcid.org/0000-0002-8687-1231;

Gladson Ricardo Flor Bertolini - Dhttps://orcid.org/0000-0003-0565-2019.

1. Centro Universitário Lusíadas, Santos, SP, Brasil

2. Universidade Estadual do Oeste do Paraná, Cascavel, PR, Brasil.

Submitted on February 25, 2019.

Accepted for publication on May 20, 2019.

Conflict of interests: none - Sponsoring sources: none.

Correspondence to:

Rua Universitária, 2069 - Jardim Universitário

85819-110 Cascavel, PR, Brasil.

E-mail: gladsonricardo@gmail.com

(C) Sociedade Brasileira para o Estudo da Dor an immense possibility of painful musculoskeletal conditions, with favorable and promising results.

Keywords: Auriculotherapy, Modalities of physiotherapy, Pain, Physiotherapy, Rehabilitation, Traditional Chinese Medicine.

\section{RESUMO}

JUSTIFICATIVA E OBJETIVOS: A auriculoterapia é amplamente utilizada para o alívio de condiçóes dolorosas, portanto, com número considerável de estudos, permitindo a realização de revisôes sistemáticas no assunto. No entanto, não propuseram um banco unificado de pontos de possível escolha, suas possíveis combinaçóes ou descreveram a localização de tais pontos, tornando-se então, o objetivo deste estudo.

CONTEÚDO: Optou-se por uma revisão sistemática de revisôes (Overview). A qualidade de tal material foi realizada por intermédio da ferramenta Assessment of Multiple Systematic Reviews e as bases de dados consultadas foram: PEDro, Pubmed, Scielo e LILACS. As palavras-chaves e índice booleano aplicados como a seguir: Auriculotherapy AND pain; ear acupuncture AND pain, ear acupressure $A N D$ pain; auricular therapy $A N D$ pain; auricular medicine AND pain. Foram encontrados primariamente 242 estudos, mas apenas seis eram revisóes sistemáticas em humanos, envolvendo dor e apenas auriculoterapia (sem associação a outra técnica). A qualidade metodológica dos estudos foi alta (8-10/11 - Assessment of Multiple Systematic Reviews). Há variabilidade na explicação neurofisiológica de ação, muitas possibilidades de afecçôes que podem ser abordadas com auriculoterapia (dores agudas, crônicas, por traumas, pré e pós-operatórias entre outras). A auriculoterapia apresentou-se como promissora na remissão da dor, meio adjunto ao tratamento convencional, baixo risco, custo e de fácil administração.

CONCLUSÂO: A auriculoterapia apresenta diversas formas de justificar seus efeitos neurofisiológicos e os pontos mais utilizados foram ShenMen, a regiáo somatotópica correspondente e a regiấo da concha cava (estimulação vagal). Atende uma imensa possibilidade de condiçôes dolorosas musculoesqueléticas, com resultados favoráveis e promissores.

Descritores: Auriculoterapia, Dor, Fisioterapia, Medicina Tradicional Chinesa, Modalidades da fisioterapia, Reabilitação.

\section{INTRODUCTION}

Since 1978, the World Health Organization (WHO) recommends the insertion of complementary and alternative medicine 
(CAM) or integrative and complementary practices (ICP) in public health systems (e.g., Unified Health System, SUS). In Brazil, ICPs increased following the approval by the Ministry of Health (MS) in 2006 to include non-pharmacological and more natural therapies, such as Tai Chi, Qigong (Lian Gong), Yoga, Mat Pilates, workplace exercises, therapeutic exercises, manipulative resources, acupuncture, and meditation ${ }^{1}$. In 2017 there was an increase in ICPs used, and auriculotherapy (AT) was included. Since AT can be applied at several levels of health care, such as basic, specialized, and hospital, the proposal is to prevent health problems, to promote recovery, health, and the non-abandonment of the conventional medicine treatment ${ }^{2-5}$. Given the effectiveness and low cost of AT, the Federal University of Santa Catarina, in partnership with the MS, promoted throughout Brazil the "Training in Auriculotherapy for Primary Care Health Professionals," enabling and promoting the integration of this resource to $\mathrm{ICP}^{6}$.

AT, ear acupuncture and ear acupressure are synonymous with centuries-old therapy via stimulation of the pinna to relieve pathological conditions in the body. AT has two main lines of reasoning that explain its principles, the French school (Paul Nogier) and the Chinese school (Traditional Chinese Medicine - TCM ${ }^{7}$. In 1957, in France, AT was driven by the cartography proposed by Paul Nogier, scheming an inverted fetus in the ear as a somatotopic map representing reflex parts of body stimulation. Theorizing that symptoms and diseases are projected in specific regions in the ear, as it is one of the few anatomical structures formed by endoderm, mesoderm, and ectoderm (three embryonic layers), which may hypothetically represent all parts of the body $^{8}$. This triggered the study of its neurophysiological basis of action and its recognition by WHO in 1987, which identifies it as an acupuncture microsystem capable of intervening in the body as a whole. The standardization of an international nomenclature took place in 1990, with updates of such information occurring to the present day, merging the two principles (French and Chinese $)^{9-11}$. In addition to Paul Nogier's view, for more than 2000 years, AT has been dated in Asian culture and explained by the regulation of "vital energy" (Qi), which circulates through the meridians and collateral channels. When there is an imbalance of a person's Qi, he/she becomes vulnerable to disease, and AT would be able to harmonize such flow by minimizing symptoms (TCM concept) $)^{7,9,10}$. AT treatment may be isolated or in combination with another intervention (e.g., kinesiotherapy), temporary, aiming at discharge, or referral to exercise groups ${ }^{1}$.

Pain, in its various forms of manifestation, is a common cause of medical consultations and other health professionals (e.g., physiotherapists), and chronic pain is prevalent in the Brazilian population equal to or greater than worldwide (10.1-55.5\%), representing one of the biggest challenges for public health ${ }^{12,13}$. It impacts the functionality, quality of life, productivity, generates economic damage (personal, family, business and government), as well as the indiscriminate use of drugs and thus their possible adverse effects. Therefore, complementary therapies are part of the list of pain control options, as they have lower risk, lower cost, and are less invasive than the usual approach ${ }^{10,11,14}$.

The concepts described serve as a starting point for AT studies. However, by focusing on the care of painful conditions, the analy- sis of its relationship with pain modulation should be understood. Neurophysiologically, stimuli at the nerve endings of the pinna are transmitted via the spinal and cranial nerves (peripheral nervous system, PNS) to the central nervous system (CNS), releasing neurotransmitters that regulate the control mechanisms of endogenous pain. When activated, the descending neural pathway releases endogenous opioids (endorphins) in the posterior horn of spinal cord (PHSC), making it difficult for the CNS to spread and perceive the pain stimulus (pain descending inhibitory pathways, extra segmental or supraspinatus mechanism). Another mechanism of nociceptive modulation is the so-called Gate Control Theory (segmental or spinal mechanism), which transmits non-painful stimuli via myelinated afferent fibers $(A \beta)$, as opposed to harmful stimuli from poorly myelinated $(\mathrm{A} \delta$ ) or unmyelinated $(\mathrm{C})$ fibers balancing painful sensation in $\mathrm{PHSC}^{15,16}$. Both routes are the most attributed to AT, aiming to justify their effects in pain conditions. Inflammation control would be linked to points in the anatomical region of the cavum conchae (e.g., lung 1 and 2), which stimulates the vagus nerve by releasing acetylcholine, a neurotransmitter that inhibits the release of tumor necrosis factor-alpha (TNF- $\alpha$, proinflammatory cytokine) by macrophages, thereby minimizing inflammation (cholinergic reflex) $)^{17-19}$.

AT points can be stimulated in a variety of ways such as seeds (mustard or rapeseed), acupuncture needles (facial or systemic), magnetic pellets, semi-permanent needles, electrophototherapy (laser or transcutaneous electrical nerve stimulation (TENS) and the fingers themselves. However, the seeds are low cost and have the advantage that patients self-stimulate the points and thus have been the most used ${ }^{7,10}$. The seeds should be stimulated three to four times a day, for a minute or until the site becomes sensitive, with weekly changes upon reassessment of the case. However, there are reports of staying with the same application for up to one month, and the total treatment time ranges from 2-10 weeks ${ }^{7,10,14}$. A systematic review with meta-analysis concluded that AT might be effective in relieving acute and chronic pain, reducing its intensity within the first 48 hours of treatment initiation, and being a safe resource ${ }^{11}$. Another study describes pain remission time ranging immediately up to 6 months ${ }^{10}$. Although there are systematic reviews ${ }^{7,8,10,11,14}$ addressing AT and pain, they did not propose a unified database of possible site choice, their possible combinations, or describe the location of such sites, thus becoming the goal of this study. In addition to mentioning the main sites indicated for painful cases, the aim was to identify their locations, facilitating the clinical practice.

\section{CONTENTS}

In order to achieve the proposed objective, a systematic review of reviews that addressed AT and pain was chosen (Overview). PEDro, Pubmed, Scielo and LILACS databases were accessed in February 2019. The keywords and Boolean indexes were used as follows: Auriculotherapy AND pain; ear acupuncture AND pain, ear acupressure AND pain; auricular therapy AND pain; auricular medicine AND pain. These words should be present in the title or abstract for the articles to be selected. If in doubt, the studies were fully verified. Filters were applied seeking only 
systematic reviews that were in humans, without restriction on the date of publication. Two evaluators made the selection and assessment by the Assessment of Multiple Systematic Reviews $(\text { AMSTAR })^{8}$ tool, discussing the score in case of divergence. Although revisions on the theme are not an unpublished subject, the report of the points or which were the most used are not always described, making clinical practice and methodological reproduction difficult ${ }^{8,11}$. Therefore, books were also consulted to provide the best description of the use of points, as well as their location. Table 1 shows the results of the selection in the databases, and table 2 shows the studies with the application of the AMSTAR tool in order of the highest score.

Figure 1 shows the subdivision of the pinna necessary to understand and facilitate the interpretation of the description of the sites in table 3. It is noteworthy that there are normal anatomical variations from person to person, so at first, the identification of the structures, as well as the search for specific sites, require practical training?.

Table 3 shows the main points for the relief of painful conditions according to the unification of several studies, and figure 2 shows where they are anatomically $\mathrm{y}^{6,10,14,22-25}$.

This does not mean that all should be applied in a single session but rather selected according to the combinations already described and added to the painful area to be treated (Figure 3).

For example, ShenMen, Kidney, Sympathetic (auriculocybernetics) + lumbar (affected region - AR). However, a systematic re-

Table 1. Search and selection of studies in the databases

\begin{tabular}{lcccc}
\hline Databases & Found & Repeated & Deleted & Final \\
\hline PEDro & 20 & 2 & 13 & 5 \\
Pubmed & 112 & 11 & 100 & 1 \\
Scielo & 33 & 0 & 33 & 0 \\
LILACS & 77 & 0 & 77 & 0 \\
Total & 242 & 13 & 223 & 6 \\
\hline
\end{tabular}

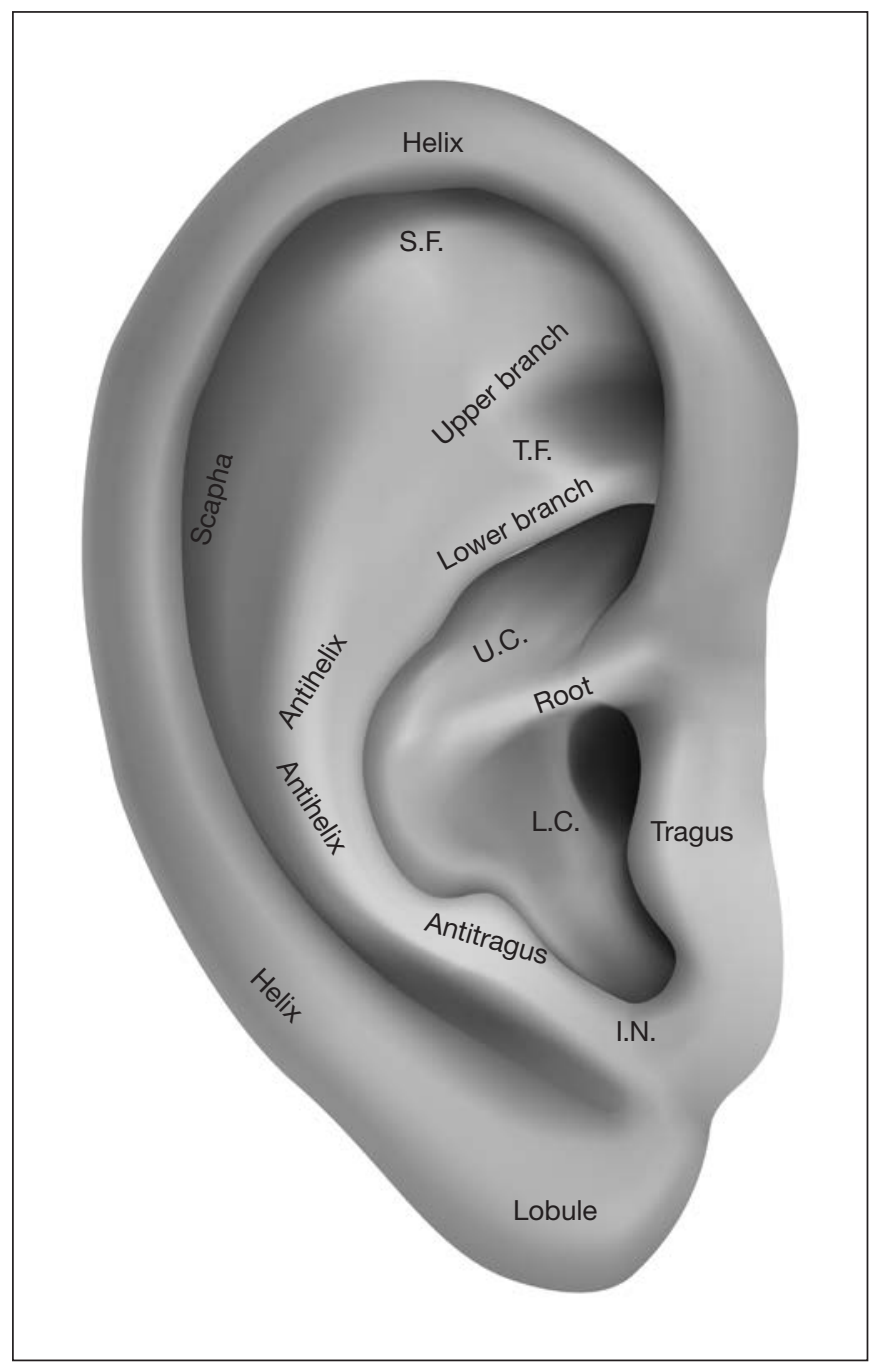

Figure 1. Anatomical division of the pinna

$\mathrm{SF}=\mathrm{Scaphoid}$ fossa; TF = triangular fossa; UC = upper conchae or cymba; LC = lower conchae or cavum; IN = intertragical notch.

Table 2. Characteristics of systematic reviews and selected meta-analyzes

\begin{tabular}{|c|c|c|c|c|c|}
\hline Authors & Objectives & Most used AT points & Results (p) & $\begin{array}{l}\text { Mean differen- } \\
\text { ces in pain }\end{array}$ & AMSTAR \\
\hline Yang et al. ${ }^{7}$ & $\begin{array}{l}\text { Effect of ear acupressure on } \\
\text { chronic low back pain }\end{array}$ & $\begin{array}{l}\text { ShenMen, subcortex, AR (lumbosacral, } \\
\text { spine, lumbar, sciatic nerve, hip, popli- } \\
\text { teal fossa), liver, kidney, sympathetic, } \\
\text { bladder, spleen, Ashi points }\end{array}$ & $\mathrm{p}<0.001$ & -1.13 & $11 / 11$ \\
\hline Zhao et al. ${ }^{20}$ & $\begin{array}{l}\text { Assess the effectiveness of AT } \\
\text { in chronic pain }\end{array}$ & $\begin{array}{l}\text { ShenMen, sympathetic, subcortex, thala- } \\
\text { mus, liver, kidney, heart, bladder, spleen, } \\
\text { lung, analgesia, AR and Ashi points. }\end{array}$ & $p<0.05$ & -3.76 & $10 / 11$ \\
\hline Yeh et al. ${ }^{10}$ & $\begin{array}{l}\text { AT effectiveness in pain mana- } \\
\text { gement compared to the pla- } \\
\text { cebo group }\end{array}$ & $\begin{array}{l}\text { ShenMen, subcortex, lung, thalamus, } \\
\text { sympathetic, liver, kidney, analgesia, } \\
\text { endocrine and AR. }\end{array}$ & $p<0.05$ & 1.59 & $10 / 11$ \\
\hline Asher et al. ${ }^{14}$ & AT in pain management & $\begin{array}{l}\text { ShenMen, thalamus, lung, heart, zero } \\
\text { point and AR. }\end{array}$ & $p<0.05$ & 1.56 & $10 / 11$ \\
\hline $\begin{array}{l}\text { Murakami, Fox and } \\
\text { Dijkers }^{11}\end{array}$ & Immediate pain relief $(48 \mathrm{~h})$ & ShenMen, thalamus, lung and AR. & $p<0.05$ & -1.08 & $9 / 11$ \\
\hline
\end{tabular}




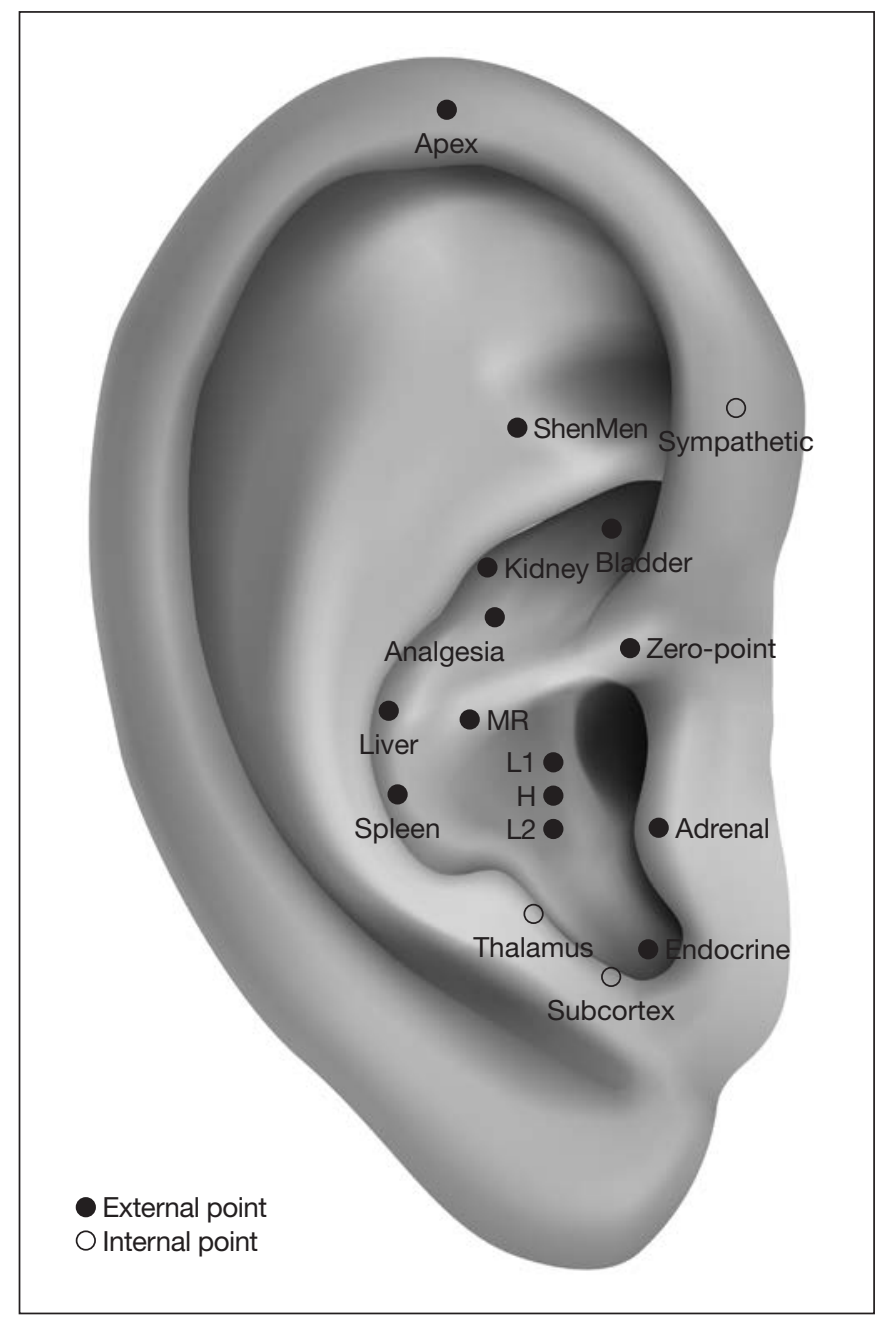

Figure 2. Location of the main analgesic points $M R=$ muscle relaxation; $L 1=$ lung $1 ; \mathrm{H}=$ heart; $L 2=$ lung 2.

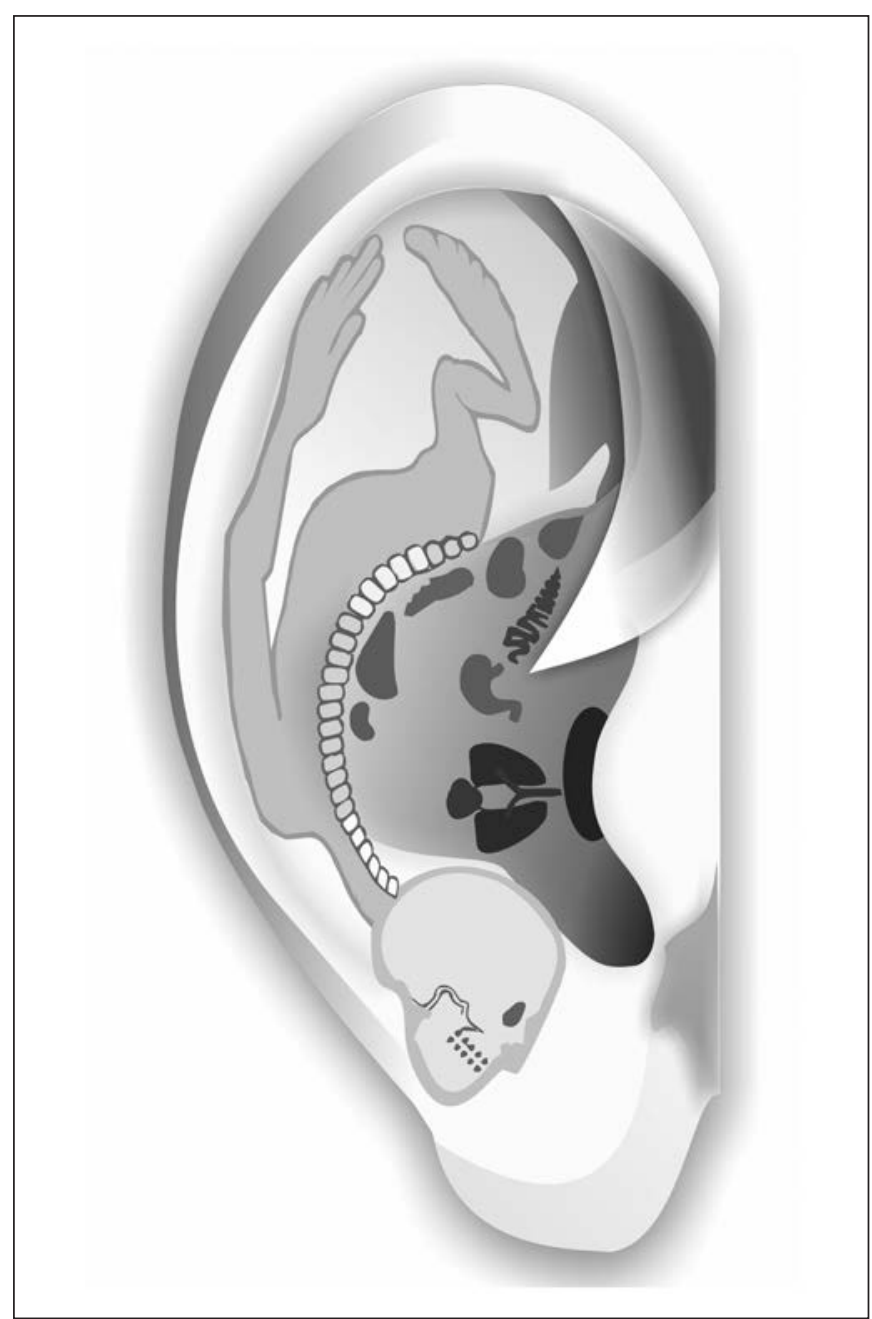

Figure 3. Somatotopic map of the reflex region affected and to be chosen to treat

Table 3. Main points to be combined with analgesic purposes

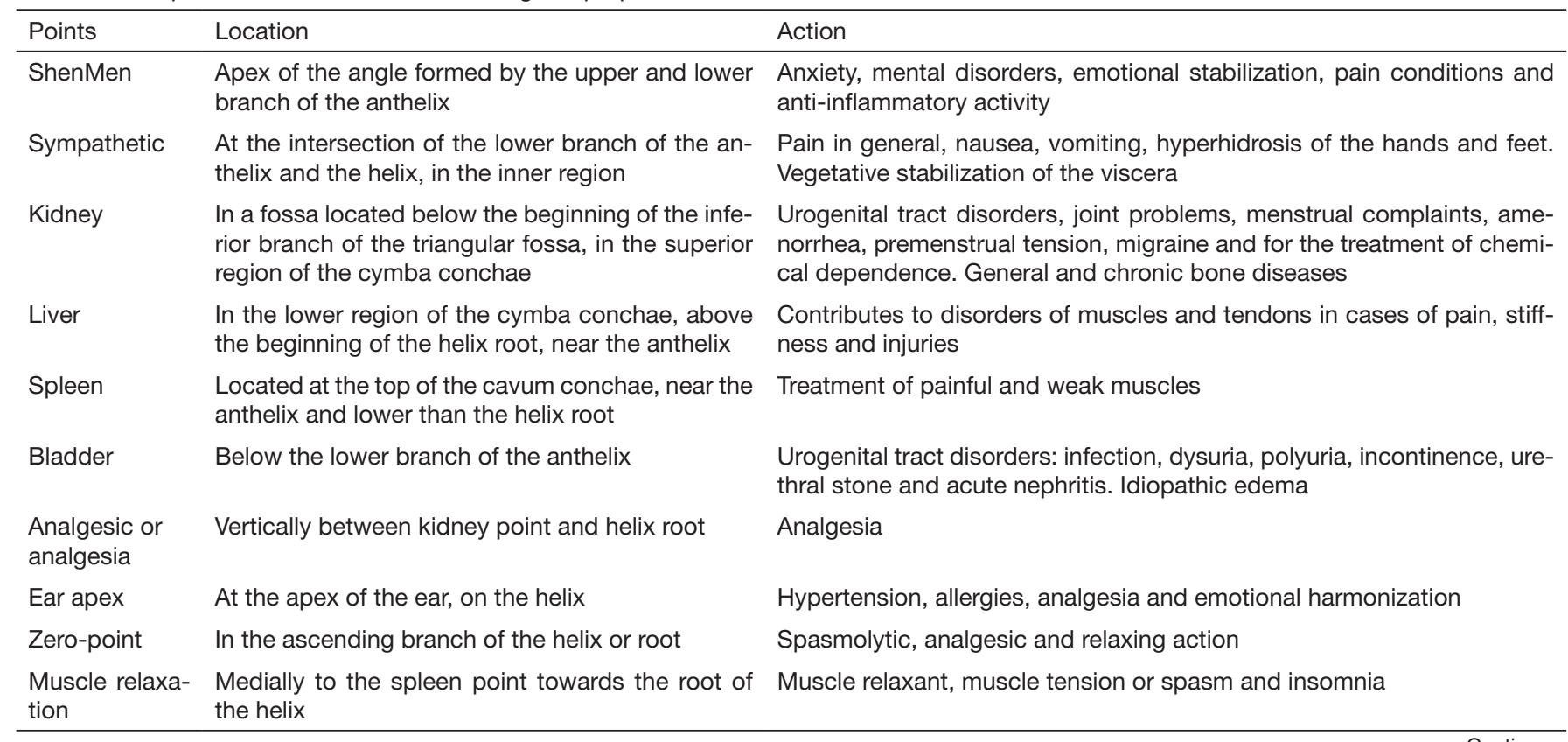


Table 3. Main points to be combined with analgesic purposes - continuation

\begin{tabular}{|c|c|c|}
\hline Points & Location & Action \\
\hline Lung 1 and 2 & In the conchae cavity surrounding the heart zone & $\begin{array}{l}\text { Respiratory tract and skin disorders such as colds, laryngitis, cough, as- } \\
\text { thma, bronchitis, dermatitis, urticaria and acne (vagus nerve stimulation) }\end{array}$ \\
\hline Heart & Cavum conchae cavity center & $\begin{array}{l}\text { Hypertension, anxiety, depression, insomnia, palpitations, tachycardia } \\
\text { and dyspnea, angina and bradycardia (vagus nerve stimulation) }\end{array}$ \\
\hline Adrenal & In the prominence of the tragus & $\begin{array}{l}\text { Articular disorders, circulatory, inflammatory processes, rheumatism, ar- } \\
\text { throsis, bursitis, allergic processes. Stimulates adrenocortical hormones } \\
\text { and adrenaline }\end{array}$ \\
\hline Thalamus & $\begin{array}{l}\text { Above the subcortex point in the inner face and } \\
\text { apex of the antitragus }\end{array}$ & Low back pain and neck pain \\
\hline Endocrine & At the inner base of the intertragical notch. & $\begin{array}{l}\text { Endocrine disorders, hypo, and hyperthyroidism, diabetes, gynecologi- } \\
\text { cal and rheumatoid disorders. }\end{array}$ \\
\hline
\end{tabular}

view demonstrated the possibility of choosing 15 different points only for the treatment of low back pain, with ShenMen and subcortex being the most frequent ${ }^{7}$. This demonstrates considerable variability among the studies analyzed, as it is suggested to select about 4-6 treatment points ${ }^{26}$. Therefore, it is impracticable to propose associations for each painful case in this format; a book would be needed to address this objective since more than 200 AT points were identified ${ }^{8}$. In any case, some previously used combinations serve as the basis, such as the described auriculocybernetics itself or the following combinations: ShenMen, thalamus, lung + affected region, somatotopic correspondence of reflexively compromised body area $(A R)^{14}$; ShenMen + AR (10); thalamus, analgesic $+\mathrm{AR})^{23}$; ShenMen, subcortex $+\mathrm{AR}^{7}$.

There have been many reported conditions where AT can help to relieve the pain. Some of these indications are as follows: 1) cancer-associated pain, knee arthroscopy, femur fracture, hip arthroplasty $^{14}$; in dysmenorrhea, postoperative pain, hip fracture, low back pain, bone marrow aspiration, acute and chronic pain $^{10}$; 2) spinal pain, lumbar sciatic pain, cramps, stiff neck, fibromyalgia, rheumatic pain, phantom pain, amputation stump pain, herpes zoster, pain after fractures in general, trigeminal neuralgia, toothache, headache, migraine and tension headache ${ }^{23}$; 3) chronic low back pain, muscle spasm, whiplash injuries, traumatic pain, inflammation after joint sprains, osteoarthrosis, pelvic and abdominal pain, shoulder impingement syndrome, adhesive capsulitis, bursitis, lateral epicondylitis, carpal tunnel syndrome and joint pain ${ }^{22}$.

Usichenko, Lehmann and Ernst ${ }^{21}$ did not state which AT points were applied in the clinical trials analyzed and their results in statistical terms, which hinders the interpretation and reproducibility of new research. This study was conducted over a decade ago, and others with the same methodological design came later, being more careful. Murakami, Fox and Dijkers ${ }^{11}$ highlighted the fact that AT has results as good as their comparative groups, has temporary adverse effects and is less degrading than medications (pain in the site, which can make it difficult to sleep, skin irritation, slight bleeding, dizziness, and nausea) and the application is quick and accessible. However, they expected a more significant reduction in pain. Asher et al. ${ }^{14}$ came to a more positive conclusion than previous authors, stating superior pain minimization results when AT was compared with a control group or placebo compared to the same comparison made with systemic acupuncture. Contradicting another systematic review, which shows that AT was not superior to the placebo group and that its effects begin to diminish three months after the end of its application, they nevertheless described it as promising and capable of reducing pain ${ }^{20}$. Jiang et al. ${ }^{18}$ found a positive and lasting effect of AT on pain and that adverse effects are insufficient for patients to abandon treatment. In order to resolve these doubts, studies such as Moura et al. ${ }^{27}$, with 110 participants, treatment group, placebo, and control, should be encouraged, as they allow reliable conclusions to be based.

The justification for the effects of AT seems to be linked not only to the penetration of the needle into the pinna but to the choice of ideal sites ${ }^{14}$. This is an extensive discussion, but four possible explanations are elucidated: (1) AT acts by a mechanism other than systemic acupuncture; (2) action similar to acupuncture, which would activate meridians, regularization of organ function, $Q i$ and Blood, with consequent normalization of painful pathways (TCM); (3) hypersensitive reflex neuronal pathways that connect the auricular microsystem to the corresponding somatotopic region in the brain, which through the spinal cord reaches the corresponding painful area; (4) AT does not depend on specific points, but rather on the stimulated region ${ }^{7,10,14,20}$. The fourth explanation comes from the stimuli in the cavum conchae region, innervated by the vagus nerve, to be able to induce parasympathetic stimulation. Therefore, analgesia would be caused by the application site and not by the selection of points. That is, AT can function via the central pain control mechanism. However, if the analgesia provided is by specific points or stimulated region, it remains under discussion ${ }^{14}$. What is known is that auricular stimulation is a scientifically validated method, even by functional non-invasive magnetic resonance imaging of brain neuromodulation ${ }^{17}$. The possibility of acting by central descending pain inhibitory mechanism was reinforced by the fact that the effects of AT are blocked by the use of the opioid antagonist naloxone. AT would still be able to increase pain tolerance. Therefore, there is variability in the explanation that indicates the action of AT in pain, but it shows the interest of the scientific community in this microsystem, making it the most studied ${ }^{7}$. Yeh et al. ${ }^{10}$ also reported significant pain relief with AT compared to the control or placebo group, noting that the quality of the studies was moderate to high. One of the difficulties with 
AT effectiveness reported by these authors would be the limited number of placebo group studies, only $32 \%$ of studies involving AT and pain. The patient expectation about the treatment, the relationship with the therapist, and the placebo effect itself may affect the results obtained with AT, but they are present in any other treatment modality. The ShenMen point and the reflex points corresponding to the affected region are the most commonly used in practice, according to the authors mentioned, information that corroborates the findings in table 2.

In short, the need for blind, randomized, sample-based clinical trials to define the number of participants should be encouraged when investigating the effectiveness of any treatment method, as well as the review of reviews. The possibility of using this study design, review of reviews, on a specific theme (AT and pain), demonstrates the interest of the scientific community in the topic. So far, the conclusions are cautious, but the systematic reviews that have been included have shown high methodological quality (8-10/11 - AMSTAR) and agree on the following aspects: AT is an adjunct technique to be used to manage pain; to reduce the use of analgesic drugs, minimizing tolerance and adverse effects. It is a treatment with low risk, low cost, and easy administration ${ }^{7,10,11,14,20,21}$.

\section{CONCLUSION}

AT has favorable results regarding its effects on pain (although its mechanisms of action continue to be studied), showing to be promising as adjunctive therapy to conventional treatment. The ShenMen point, reflex points corresponding to the site in the affected body, and cavum conchae stimulation (e.g., lung point), seems to be the most favorable combination for better pain relief results.

\section{REFERENCES}

1. Tesser CD, Sousa IM, Nascimento MC. Práticas integrativas e complementares na atenção primária à saúde brasileira. Saúde Debate. 2018;42(n. spe1):174-88.

2. Jackson C. Trends in the use of complementary health approaches among adults in the United States: new data. Holist Nurs Pract. 2015;29(3):178-9.

3. Organization WH. WHO Traditional Medicine Strategy. Alternative and Integrative Medicine. 2013. 1-78p

4. Schveitzer MC, Esper MV, Silva MJ. Práticas integrativas e complementares na atenção primária em saúde: em busca da humanizaçáo do cuidado. Mundo Saúde.
2012;36(3):442-51.

5. Clarke TC, Black LI, Stussman BJ, Barnes PM, Nahin RL. Trends in the use of complementary health approaches among adults: United States, 2002-2012. Natl Health Stat Report. 2015;10(79):1-16.

6. UFSC UF de SC - Formação em auriculoterapia. In: Formação em auriculoterapia para profissionais de saúde da atenção básica. 2018.

7. Yang LH, Duan PB, Hou QM, Du SZ, Sun JF, Mei SJ, et al. Efficacy of auricula acupressure for chronic low back pain: a systematic review and meta-analysis of randomized controlled trials. Evid Based Complement Alternat Med. 2017;2017:6383649.

8. Vieira A, Reis AM, Matos LC, Machado J, Moreira A. Does auriculotherapy have therapeutic effectiveness? An overview of systematic reviews. Complement Ther Clin Pract. 2018;33:61-70.

9. Alimi D, Chelly JE. New universal nomenclature in auriculotherapy. J Altern Complement Med. 2018;24(1):7-14.

10. Yeh CH, Chiang YC, Hoffman SL, Liang Z, Klem ML, Tam WW, et al. Efficacy of auricular therapy for pain management: a systematic review and meta-analysis. Evid Based Complement Alternat Med. 2014;2014:934670.

11. Murakami M, Fox L, Dijkers MP. Ear acupuncture for immediate pain relief-a systematic review and meta-analysis of randomized controlled trials. Pain Med. 2017;18(3):551-64.

12. Carvalho RC, Maglioni CB, Machado GB, Araújo JE, Silva JR, Silva ML. Prevalence and characteristics of chronic pain in Brazil: a national internet-based survey study. BrJP. 2018;1(4):331-8.

13. Vasconcelos FH, Araújo GC. Prevalence of chronic pain in Brazil: a descriptive study. BrJP. 2018;1(2):176-9.

14. Asher GN, Jonas DE, Coeytaux RR, Reilly AC, Loh YL, Motsinger-Reif AA, et al Auriculotherapy for pain management: a systematic review and meta-analysis of randomized controlled trials. J Altern Complement Med. 2010;16(10):1097-108.

15. Damien J, Colloca L, Bellei-Rodriguez CÉ, Marchand S. Pain modulation: from conditioned pain modulation to placebo and nocebo effects in experimental and clinical pain. Int Rev Neurobiol. 2018;139:255-96.

16. Quah-Smith I, Litscher G, Rong P, Oleson T, Stanton G, Pock A, et al. Report from the $9^{\text {th }}$ International Symposium on Auriculotherapy Held in Singapore, 10-12 August 2017. Medicines. 2017;4(3):46. pii: E46.

17. Mercante B, Deriu F, Rangon CM. Auricular neuromodulation: the emerging concept beyond the stimulation of vagus and trigeminal nerves. Medicines. 2018;5(1). pii E10.

18. Jiang Y, Cao Z, Ma H, Wang G, Wang X, Wang Z, et al. Auricular vagus nerve stimulation exerts antiinflammatory effects and immune regulatory function in a 6-OHDA model of Parkinson's disease. Neurochem Res. 2018;43(11):2155-64.

19. Mercante B, Ginatempo F, Manca A, Melis F, Enrico P, Deriu F. Anatomo-physiologic basis for auricular stimulation. Med Acupunct. 2018;30(3):141-50.

20. Zhao HJ, Tan JY, Wang T, Jin L. Auricular therapy for chronic pain management in adults: a synthesis of evidence. Complement Ther Clin Pract. 2015;21(2):68-78.

21. Usichenko TI, Lehmann Ch, Ernst E. Auriculoterapia para el control del dolor postoperatorio: una revisión sistemática de ensayos clínicos aleatorizados. Rev Int Acupunt. 2009;3(3):130-2

22. Oleson T. Auriculotherapy Manual: Chinese and Western Systems of Ear Acupuncture. $4^{\text {th }}$ ed. Churchill Livingstone; 2013.

23. Kajsa L. British Library Cataloguing in Publication Data. $1^{\text {st }}$ ed. Churchill Living stone; 2008.

24. Souza MP. Tratado de auriculoterapia. Look; 2000. 3p.

25. Garcia EG. Auriculoterapia. ROCA; 1999. 50p.

26. Levy CE, Casler N, Fitzgerald DB. Battlefield acupuncture: an emerging method for easing pain. Am J Phys Med Rehabil. 2018;97(3):e18-9.

27. Moura CC, Iunes DH, Ruginsk SG, Souza VHS, Assis BB, Chaves ECL. Action of ear acupuncture in people with chronic pain in the spinal column: a randomized clinical trial. Rev Lat Am Enfermagem. 2018;26:e3050. English, Portuguese, Spanish. 